\title{
The American Quest for Identity: Theme and Form in the Catcher in the Rye, Invisible Man and Slaughterhouse Five
}

\author{
Abdulaziz H. AlAbdullah \\ Kuwait University, Kuwait, Arab
}

\begin{abstract}
American society went through some especially speedy and drastic changes, after the World War II. Its transformation into a significant superpower as well as the horrors of the recent conflict is reflected in specific American novels and in the writing of certain elite novelists. They focus on human loss and a consequent search for identity and problematic belonging in a world of prejudice and hostility. This search for identity and aspiration to conformity with the new change is among of the main features of Salinger's the Catcher in the Rye, Ellison's Invisible Man and Vonnegut's Slaughterhouse Five. The paper focuses on certain similarities in theme and form which link these three novels and examines the extent of presentation of the style of narration set in motion by all three writers.
\end{abstract}

Keywords: identity, theme, form, the Catcher in the Rye, Invisible Man, Slaughterhouse Five

\section{Introduction}

In a relatively small number of decades, America went from no significant power to that of a great broker of super-power. It passed from an age of innocence into an age of imposing dread and affluence. Throughout this process, the individual seemed powerless in the force of external pressures. The average citizen felt the need to escape from this pressure to discover an inner self, in order to find an identity as a separate human being, not as a minimal factor in a large group.

In the American novel of the 20th century, relating to this quest for identity was a prominent theme. Most subsequent themes in such novels seem to build upon one central concern: man's need to escape the multi-faceted pressure that society imposes upon him. In each novel, this needs to escape takes a different form, thus treated in a myriad different ways.

In the second half of the 20th century, novelists were also concerned with bloodied modern history and its terrifying effects on society. In many of the novels, history is treated as a "landscape of lunacy and pain".

In treating history that way, the writers doubted the rationality and logic of the idea of life. They consequently saw an inner psychic disorder. This is what they bring out in their heroes.

Thematic similarities are these they find in American novels, rather than similarities of form or style. The themes dealing with slight change or variation recur in many novels of the 50s, 60s or 70s. These writers show a world of tragic disarray, so vast as to be beyond explanation; the heroes of these novels go through the traumatic experience of living and having to survive in an emotionally mutant world. The hero is often a

\footnotetext{
Abdulaziz H. AlAbdullah, Faculty of Arts, Department of English Language and Literature,Kuwait University.

Correspondence concerning this article should be addressed to P.O.BOX 23558, SAFAT - 13096, KUWAIT. Email: azizalabdullah@yahoo.com.
} 
lonesome individual, completely alienated from society and its norms of behavior. Tony Tanner(1979)points out how between the lone American self and the rest of the world, there is, indeed, very often a void. The solution that many novels propose for this lone alienated self is for him to be assimilated to a conventional social group and to hide deep inside it so as to be able to wander and be active in it without being detected for what he really is: Be a type of non-conformist. Elsewhere, the hero revolts against society and any label that is imposed around its members.

Generally speaking, the American writer explicates an effort to depict society, to address the question what America amounts to, and to state how an individual can relate to it. Various authors are battling to discover the identity of America, to find a unitary form in which it would fit. As long as that remains, for the writer, an unaccomplished goal, so long the American novel will remain a "search", it is search to identify society and self. For that reason the themes and concerns of the American novel have not changed drastically during the five decades. The authors use different forms of narrative, some more, others less conventional. They adopt different styles and different languages. But their main preoccupation is the same.

Here talking about three American novels, characteristic of the American thought and society as they are seen through the immense imaginary crucible of literature.

\section{Literature Review}

J. D. Salinger's the Catcher in the Rye, Ralph Ellison's Invisible Man and Kurt Vonnegut's Slaughterhouse-Five, were written in 1951, 1952 and 1970 respectively. They have strong thematic similarities. Their difference in style, form and language is also conspicuous. Let them assess similarities in theme and image, in these novels, and then look into the different approaches their authors used to construct congruous form and style for their books.

Initially, these three novels are all the account of an experience that the central character, the hero has had: Holden Caufield is telling them about his "adventurous" three days after he left Dencey Prep. School. The narrator in Invisible Man is recounting the experiences of his life which ultimately led him to discover his invisibility. In Slaughterhouse-Five, Vonnegut tells of his traumatic experience in Dresden during the Second World War. There isn't much to tell, he admits. Everything is usually very quiet after a massacre. As the central characters go through their experiences they discover things in themselves, they see elements in their characters that they had previously not recognized, and they learn things about their inner and the outer world that they did not know. In other words, they go on an educative journey, they learn lessons about life. They mingle with the crowd and other individuals. They gain experience. They are seeking to make sense of their lives that have been "made absurd by society and history".

Holden is a young boy of 15 who runs away from school. He is an adolescent who is disgusted at the sordidness and falsity of the adult world. He exists in the constant fear that everyone and everything around him will do something phony. His three days of wondering seem to prove all his fears true. He meets people and goes places and every single time the adults fail him. He wishes to believe in a protective, caring world and that is what he goes looking for. He feels totally let down as he gradually realizes that no such consolation exists. He is on the edge of adulthood though he refuses to realize it. Subconsciously he is fighting it. He is repeatedly told to grow up but he likes to think of himself as belonging to the innocent side of life's reality: childhood. Nevertheless, Holden would have entered the adult world if only he had known how to. He is looking for a non-phony redeemer adult to help him into his adulthood. Even at that point, adults fail him: His 
history teacher, Mr. Spencer, fails to understand him and makes him feel sad as hell. His 'phony' wishes of good luck make Holden want to run away. Later on, he turns for help to the one adult he knows isn't phony: another teacher, Mr. Antoloni. The final blow which hits Holden very hard is when he realizes that Antoloni is as phony as all the others - even more so for having deceived Holden of his 'genuineness' as an adult. Really Holden's educative journey seems to have failed in its purpose. Holden has not been able to adjust to the adult world experiences have alienated him instead of helping him to compromise and become part of some valid social group. Instead of building a new world, his experiences help bring down his own world. Holden finds himself in a special void between childhood and adulthood, truthfulness and 'phoniness', individual and society. Then he ends up in a mental home.

The narrator in Invisible Man goes on a journey that lasts for years and costs him more in psychological and emotional strain. He lives a childhood of uneventful innocence in the South, until he is sent to a state college for Negroes supported by Northern philanthropy which is the first instructional episode of his educative journey. There he fails to learn that the basic principle is "play the game but don't believe it”. He continues believing this is why he is let down again and repeatedly. The second stage of his journey is factory work in New York. During his short stay, he realizes that society imposes “false surface on things": At the paint factory in which he works, his job is to mix in a black constituent which produces a dazzling Optic white paint. The point that is clearly made is that they are 'caught in the official version of reality', since the narrator sees a shadow of gray in the paint which his overseer — standing for the majority of people — cannot detect. He then moves on to another stage. $\mathrm{H}$ gets exposed to the current of Negro ferment in Harlem: a "back to Africa" anti-colonialist movement and a communist-like organization, the Brotherhood. He believes again and is disillusioned as a consequence; he believes that he is free. When it's too late he realizes that once again he's been used. All he wants is to fit in, which plays the role demanded of him. But he always manages to put a foot wrong. Along his journey he's been looking for a group to belong to, believing that being recognized by the others would signify that he had found his own identity. It is crucial for him when he realizes that " I wanted freedom, not destruction...I could no more escape than I could think of my identity. Perhaps, I thought, the two things were involved with each other. When I discover who I am, I'll be free” (Ellison, 1987, p. 198). This realization is an essential part of his education. What he does learn is that he wants to be a part of reality but not a puppet used by others to fit their schemes; he wants to make the own pattern for his own life.

Their third hero, Billy Pilgrim, undergoes Vonnegut's own wartime experience. He meets hostility, untruthfulness and shallowness in his social life. These experiences lead him to take refuge on a remote planet, Tralfamadore. Having been to Tralfamadore, Billy becomes "unstuck in time”. His journey is a pilgrimage (as his name indicates), which teaches him useful things about life. As Billy moves through time, he sees the significance of other people's grief through a new perspective. From the Tralfamadorians, he learns that all things that exist from past to future can be seen as eternally present. "All time is all time" the Tralfamadorians tell him, "It does not change. It does not lend itself to warnings or explanations. It simply is. Take it moment by moment, and you will find that we all are...bugs in amber” (Vonnegut, 1986, p. 61). That means that anything that happens is exactly what has to happen. That is why the Tralfamadorians think it is ridiculous of "Earthlings" to talk of "free will”. No such concept exists, for Billy to believe this, meaning that he can now see everything that's happening, has happened or will happen in his life, traumatic, unhappy or happy, as merely an event. He "becomes completely quiescent, calmly accepting everything that happens as happening exactly as it ought to...he abandons the worried ethical, tragical point of view of Western man and adopts a 
serene conscienceless passivity".

The three characters seem confront a problem which is the main subject in recent American literature. They seem entangled in a maze with no way out: They want to find an alternative to dropping out of social life completely or becoming engulfed in playing the role society imposes. For Holden Caufield, there seems to be no solution; he can't face social reality, he can't be what he's expected to be, so he ends up in an institution. The invisible man discovers his inner freedom and realizes that there is only one way to lead his life: struggling against both fixity and chaos, in order to create himself and be invested in the meaning of his experience. Billy Pilgrim fights against the fixity of social norms and the fluidity of chaos by becoming an observer of life rather than taking an active part. This is finding "reason and some degree of sanity and dignity in what seems to be a meaningless universe".

Even though two out of their three heroes are cumulative characters and learn from their experience, all three of them go through a stage when they have to pass from the world of innocence, the "real" world of atrocity, cruelty, war and death; they all there show a fear of that world and endeavour to keep away from it, as long possible.

For Holden that is the deepest and most prominent problem: He feels he is gradually being pulled into the adult world. He struggles with all his might against it. He wishes to stay with the pre-social and pre-sexual innocence and security that childhood offers him. He is aware of the falsity of the modern world yet he is sensitive to its fugitive beauty. They could say he has an "adolescent” perspective, halfway between childhood and the adult world, being fully a part of neither yet acutely sensitive to both. His fear at entering the adult world totally is extended beyond himself; his whole idea of being a catcher in the rye comes from his desire to protect the children who are playing in a field of rye which is next to a cliff - the cliff over which one falls into adulthood. His job will be - as he dreams of it - "to catch everybody if they start to go over the cliff'(Salinger, 1986, p. 180). A further indication of his will to stay a child is the fact that the two people whom he considers his mentors are his dead brother Allie and his kid sister Phoebe. Allie died in adolescence. Therefore he stayed a child forever, never fell over the cliff. Phoebe is still a child, a young school-girl whom Holden wishes could, like things in a museum, always stay the way she is now and never have to grow up. Holden himself wants to stay a child forever and never become a "phony" adult.

The narrator in Invisible Man, like Holden, is anxious to hide in the innocent microcosm that college offers him. He is terrified at leaving its security and going out into the world of the big city with no one or nothing to protect him from the agony that he experiences facing the truth. Furthermore when he is finally exposed to the outer world he seeks to hide behind the identity that an organization gives him; thus he feels he is part of those who control society. At some point the narrator is enthusiastic about the Party, "because it gives the world a meaningful shape and himself an important role in it". To use his own words, "The organization had given the world a new shape, and me a vital role...everything could be controlled by our science. Life was all pattern and discipline”. (Ellison, 1987, p. 308) Thus he identifies with the Brotherhood. Much later he realizes that by hiding behind a given identity he was neither free nor innocent. He recalls the vet's warning on the Golden Day that "he will have to create an identity not rely on assuming one already waiting for him", so he loses his innocence. As a result he discovers his true identity and gains his freedom.

When they come to Billy Pilgrim, they find a man who, having unwillingly lost his innocence, is struggling to regain it. His innocence was lost when he, as a young man, went to war. His intention from that instant is to find a way to return to the innocent world that the war had shattered to pieces. His one refuge is 
Tralfamadore where innocence prevails among the inhabitants. While he is on the planet, he is put in a large cage in a zoo, for all the Tralfamadorians to look at and ponder. He is "displayed" in a "simulated Earthling habitat"and has no privacy. He felt perfectly happy there. His experience in the "dome" with Montana Wildhack is one which he fondly recalls. Life on Tralfamadore and in the dome symbolizes a life of happiness and innocence so Billy has no desire to leave it even if he does not have full freedom of movement there. Another part of his life which indicates his wish to return to his lost innocence is his profession: He is an optometrist who prescribes corrective lenses for "Earthling souls” (Vonnegut, 1986, p. 26). As he himself puts it, it is not for their eyes that the corrective lenses are given but for their souls; he wishes to show "Earthlings" the way back to innocence by helping them see things in the Tralfamadore way. At last element that indicates Billy's desire for the whole world and not only himself to become innocent, is the incident of his anachronistic, end-to-beginning viewing of a certain war film. The planes have magnetic power with which they shrink the fires over a German city and gather them onto steel containers which they store safely in the planes. Back in their base, the containers are taken from the planes and dismantled. The contents are separated into minerals and finally put into the ground, hidden carefully "so that they would never hurt anybody ever again" (Vonnegut, 1986, p. 54). As His vision is one of restored wholeness and renewed innocence. It is significant that Billy is killed while he addresses a large crowd on the true nature of time by a soldier that was with him in Dresden; he is killed by a symbol of war, of violence, of horror. Few seconds earlier he ends his speech with these words "Farewell, hello, farewell, hello" (Vonnegut, 1986, p. 97). As manifesting in this way the ever present possibility of renewal and return to innocence through the imagination.

It is characteristic of the three heroes that they are non-conformists and considered as such by the other members of society: Holden has a negative attitude towards anything or anyone that stands for conformity. He defies the educational system by being expelled and running away from Pencey. He feels revulsion for the bourgeois way of life that characterizes his parents and all their friends. There is hardly anything in the world of social conformity that he likes. His sister very cleverly sums him up at one point 'You don't like anything that's happening'. (Ellison, 1987, p. 76) Yet Holden does like many things, especially those that stray away from the accepted social pattern 'things that glisten and shine outside the middle of life'.

For one thing, he likes digression. He likes the dead Allie who used to write poems all over his baseball mitt, and that Jane Gallagher who kept all her kings in the back row, and Phoebe riding on the Carousel. He finds 'digression' from the pattern more attractive, more stimulating and infinitely more interesting.

As for the narrator of Invisible Man, he is facing a most perplexing problem: 'Can a man achieve any visible shape or role if he refuses to join any of the existing patterns?' Life on the surface suggests the fixity and rigidity of social roles, whereas the fluidity of life underground suggests total absence of life. 'In hibernation you can become visible to yourself, but to remain in hibernation indefinitely is simply to die' (Ellison, 1987, p. 467). If he rejects both the possibilities, where can he go, what he can do? What he gradually realizes is that he cannot experience reality without some form of patterning. If he lives too long in one pattern he is likely to become sealed off from contact with reality altogether. What he finally decides is to 'come out' because as he confesses 'I've overstayed my hibernation, since there's a possibility that even an invisible man has a socially responsible role to play' (Ellison, 1987, p. 468). He does not intend to conform to a given social role once again. He is not keen to become a 'controller' as he once was. He is coming out no less visibly, 'but coming out nevertheless' (Ellison, 1987, p. 468). He will move freely within society but will not conform, will not play a role in any alien scheme. 
Vonnegut, is a non-conformist in more ways than one. The form of his novel is in many ways a symbol of non-conformity. Billy Pilgrim is a character who doesn't conform to the accepted social norms either. After first becoming unstuck in time, or rather after he realizes his ability to do so, despite others' opinion about him, he is determined to tell people the truth, to let the public know about the 'true vision'. Thus his daughter and many other friends consider him senile, which he has suffered brain damage because of a previous plane crash in. Yet Billy cannot be held back: He gets on an all-night radio programme and talks about his experience on Tralfamadore; he gives speeches to large audiences on the true nature of time and death. He refuses to be put in the frame of an Earthling concept of time; he does not wish to be a 'bug in amber' In Invisible Man the narrator is concerned with death of the individual as a member of society.

In Catcher in the Rye death seems to plague young Holden's mind. He is wandering in a world of loneliness, alienation and 'phoniness'. His sense of alienation has reached such a stage that he starts having illusions about not being able to reach the other side of streets. He thinks he'll go 'down, down, down' (Salinger, 1986, p. 204) and disappear completely. The only person that can save him from his nightmare feelings, the only person that he calls to help is his dead brother Allie: 'Allie doesn't let me disappear. Allie doesn't let me disappear. Please, Allie'. Furthermore, the idea that the ducks in Central Park might die in the winter haunts him continuously, death intrigues Holden. His love for his dead brother and his concern with the ducks show his longing for the absent true life. He wishes to believe in a protective caring universe and the 'unfair' death of his brother and the Central Park ducks prevent him from doing so, since their deaths expose an universe of complete haphazardness to his innocent mind.

In Slaughterhouse-Five death is one of the main themes. The writing of this novel was activated by the author's horrifying experience in Dresden. 'Confronted with an overwhelming quantitative and qualitative reality of death', feeling simultaneously a revulsion for the experience of a mass death and a possible guilt for having illogically survived it, Vonnegut sets out to discover a rational explanation of death, to soothe the wounds that he has been suffering since the war. Indeed Billy Pilgrim succeeds in finding the answer, outside the world of the great explainers, in Tralfamadore. Death, he is told, is just another experience and as such requires no logical explanation:

The mot important thing I learnt on Tralfamadore was when a person dies he only appears to die. He is still very much alive in the past, so it is very silly for people to cry at his funeral... when a Tralfamadorian sees a corpse; all he thinks is that the dead person is in a bad condition in that particular moment, but that the same person is just fine in plenty of other moments (p. 25).

The Tralfamadorians, they avoid 'the duty dance with death by ignoring death as a finality'. Their little phrase 'so it goes' that Billy Pilgrim repeats ritualistically throughout the novel whenever any death is mentioned, serves as a source of renewal and by dismissing death as 'just another experience' it becomes a sign which indicates the human will for survival and perpetuation of life. They should once again consider the significance of Billy Pilgrim's profession: His corrective lenses are there to serve the purpose of revealing to all Earthlings who suffer from defective vision the meaninglessness of individual death. Billy's death is symbolic in another way. Thomas Le Claire (1975) mentions in his article 'Death and Black Magic' that Billy finally accedes to his murder by another survivor of Dresden as the ultimate affirmation of this Tralfamadorian faith in the irrelevance of death's finality'.

Let them consider the closing scene of the novel. It is springtime in Dresden and the war has ended. The 
trees bear their new leaves. The streets are silent and empty. The only thing that Billy sees on the street is a 'wagon' drawn by two horses. The wagon was green and coffin- shaped. Birds were talking. One bird said to Billy Pilgrim, "Poo-tee-weet" as a symbol of renewal and the defiance to the finality of death.

Looking at the body, form and style, the author's use of language, the type of narrative and how these novels can be considered characteristically American.

The Catcher in the Rye, written before the other two novels, is a straightforward narrative. Though there are symbolic references, the novel can be read as natural or realistic. Salinger uses a first-person narrator, an unitary voice. Everything is seen from Holden's point of view and reported in his teenage vernacular. Furthermore the use of time in the novel is basically conventional. One aspect of its form has to do with going back in time, the experience is being related by the narrator after its final outcome; in other words he is in the mental home when he decides to write and tell us how it happened, what he went through before being taken there.

In Invisible Man there is a dense use of symbols which prevents the novel from being read naturalistically. The actual invisibility of the narrator is the first and strongest symbol. Others recur throughout the novel though they become more complex and implicit as the narrative progresses. Ellison has given an explanation for this in an interview. He tells of how he changed the style of the novel as the narrator moved from the South to the North and finally into a very intricate, personal, deep 'underground area' of his soul. At the beginning, the South and the College seem naturalistic. As the narrator moves to the North, to New York and into the Brotherhood, the style becomes expressionistic; finally when the narrator drops into his hole and becomes invisible, the style becomes surrealist. Each of these writing models expresses the narrator's state of mind during that specific period of his life.

In Invisible Man as in the Catcher in the Rye, they have a first person narrator but with the stylistic variations. There is another common element between the books' narrators and the form in which the novels have been written. The narrator of Invisible Man, like Holden starts his narration from the end, i.e. he is living in his small underground room flooded with light from 1,369 light bulbs. Here he chooses to tell them of his experience and of how he became invisible.

Both Holden and the unnamed narrator are relating their experience for the same reason: By putting their experience down in 'black and white' they overcome the intensity and psychological stress of their traumatic encounters with society and other individuals. By bringing out what they've suffered and been suffocated with, they release themselves from the bonds that held their minds tied to facts. They are able to look back and think over everything they went through. They liberate themselves, they discover a new life, and they acquire a new identity. In other words they find freedom in words.

More than once they address themselves to the reader, reminding him that they wrote in order to free themselves from the burden of their experience by sharing it with others. The moment Holden finishes telling his story he feels relieved. He doesn't understand why he told them everything that happened to him, and he admits he feels sorry for having told too many people about it but that now he misses everybody he told about. He has overcome his experiences to such an extent that not only can he go back and remember them without fear or reluctance, he already misses the people and things that caused him so much pain. He ends with giving the reader a piece of advice 'Don't ever tell anybody anything. If you do, you start missing everybody' (Ellison, 1987, p. 220). 
The narrator in Invisible Man shares the same feelings. His memories haunt him: He feels guilt and confusion, he asks the reader to lend him an attentive ear and he begins with his recollections 'But what did I do to be so black and blue? Bear with me' (Ellison, 1987, p. 16). A dream of his mother speaking to him seems to bring back the possibility of freeing himself by sharing his experiences with others, before him. When he asks her what freedom is, she answers '...it isn't nothing but knowing how to say what I got up in my head'(Ellison, 1987, p. 14). The narrator finds his freedom by relating his experiences, by telling them what he's got in his head. He also gains liberation from his dark underground room. As he stated from the very beginning '...I love light...light confirms my reality, gives birth to my form. ...Nothing ... must get in the way of our need for light and ever more and brighter light. The truth is the light and light is the truth'(Ellison, 1987, p. 10). He claims that there is plenty of light in his underground room, but that it is only artificial light. By writing about and re-living his experience he is able to leave his hibernation and come out again; he comes into the world of social responsibility, of real freedom, of true light and not artificial light.

So writing is a kind of catharsis for the narrators in both novels. Concerning Slaughterhouse-Five, though the writing of the novel brought catharsis to the author himself, the form and style are so different that it has to be considered apart. The element of its form which makes it different is the total absence of time linearity. There is a non-linear but circular use of time, and the novel itself has a circular structure. Vonnegut (1986) hints about its non-linearity very early on, in the non-fictional part of the novel. He says that he thinks 'of how useless the Dresden part of [his] memory has been, and yet how tempting Dresden has been to write about' and he is reminded of a certain song:

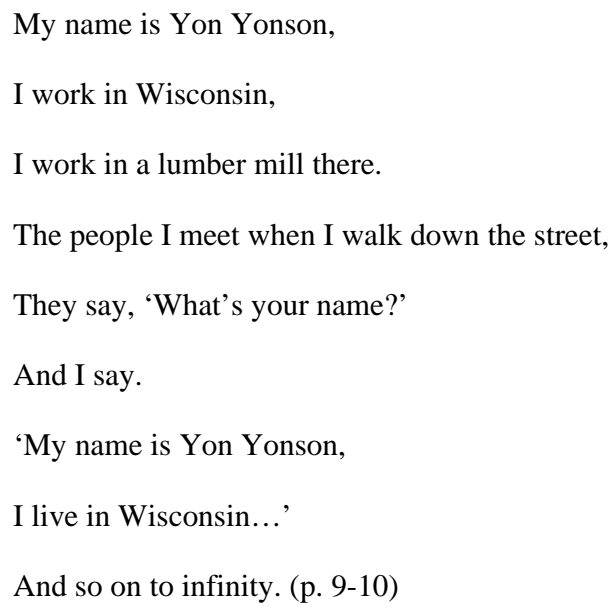

The message of the song, which is cyclical both in form and content, is that life is cyclical itself. Thus both the form and the theme of the novel are implied by it. Slaughterhouse-Five seems to be the closest attached to the Tralfamadorian novel rather than any other novel tradition. When Billy notices that the Tralfamadorian novels are similar to telegrams he is told that:

There are not Telegrams of Tralfamadore. But you're right: describing a situation is a brief urgent message describing a situation, a scene. We Tralfamadorians read them all at once, not one after the other. There isn't any particular relationship between the messages, except that the author has chosen them carefully so that, when seen all at once, they produce an image of life that is beautiful, surprising and deep. There is not beginning, no middle, no end, no suspense, no moral, no causes, or no effects. What we love in our books are the depths of many marvelous moments seen all at one time. (p. 62-63) 
Vonegut's novel is not without a climax or denouement, without beginning or end. Its circularity suggests rebirth and renewal. Through this particular form Vonnegut manages to shake himself free of the Dresden experience. The fixity of the mass death in Dresden is overcome by the fluidity of the novel's form. Vonnegut goes on living through the aid of his Tralfamadorian fiction; he cannot change the facts of Dresden, but he can survive it by the use of his imagination. Vonnegut himself said about this novel:... 'It was a therapeutic thing. I'm a different person now. I got rid of a lot of crap'. Using the idea of regeneration in theme and form, the author turned Slaughterhouse-Five into a means for deconstructing his past and rebuilding his future.

\section{Conclusion}

Through the form of the narrator in all three novels that writer is relieved from the burden of his traumatic experience. He discovers a new self, a new life and lives anew.

The Catcher in the Rye, Invisible Man and Slaughterhouse-Five, illustrate the American Literary tradition of their century. They meet an incomplete, immature hero who is in search of a definite identity. All three novels are about 'being American', and they expose the helplessness, loneliness and alienation of the individual in American society. Their forms and approach to language show the changes that occur in modes of writing and expression. At the same time their common themes serve to strengthen the belief that though their society homes in technological supremacy, the individual feels more lost, alone, secluded and alienated from the social group.

\section{References}

Bradbury. Malcolm. (1985). The Modern American Novel. Chapter 7, p158. Oxford: Oxford University Press.

Bradbury, Malcolm.(1985). The Modern American Novel. Oxford: Oxford University Press.

Costello, Donald, P.(1963). 'The language of the Catcher in the Rye' in Studies in J.D. Salinger, M. Laser, N. Fruman eds. New York :The Odessey Press.

Ellison. Ralph. (1987). Invisible Man. UK: Penguin.

Fiedler, Leslie, A.(1984). Love and Death in the American Novel.

Godshalk, William, L.(1973). 'Vonnegut and Shakespeare: Rosewater at Elsinore’ in Critique, Volume XV, No. 2, p37-48.

Gutwillig Robert.(1963). ‘Everybody’s Caught The Catcher in the Rye’ in Studies in J.D.Salinger, M. Laser, N. Fruman eds. New York: The Odessey Press.

Le Claire. Thomas. (1975). “Death and Black Humor”, Critique, Volume XVII, No. 1, p23.

Le Claire, Thomas.(1975). 'Death and Black Humor’ in Critique, Volume XVII, No. 1, p5-40.

McGinnis. Wayne.(1975). “The Arbitrary Cycle of Slaughterhouse-Five: A Relation of Form to Theme”, Critique, Volume XVII, No. 1, p59.

McGinnis, Wayne, D.(1975). 'The Arbitary Cycle of Slaughterhouse-Five: A Relation of Form to Theme' in Critique, Volume XVII, No. 1, p55-68.

McSweeney, Kerry.(1978). 'Salinger Revisited’ in Critical Quarterly Volume 20, No. 1, p61-68.

Salinger. J. (1986). The Catcher in the Rye. UK: Penguin Books Ltd.

Tanner. Tony. (1977). The Reign of Wonder(p.337). Cambridge: Cambridge University Press.

Tanner. Tony. (1979). City of Words: American Fiction 1950-70(p.53). UK: Jonathan Cape Paperback.

Vonnegut. Kurt. (1986).Slaughterhouse-Five. UK: Triad Grafton Books. 